\title{
The Evaluation of Edmodo in Business Reading Class
}

\author{
Rinda Warawudhi
}

\begin{abstract}
Several social media have been adopted in the digital 21st-century classroom. Edmodo is one of free social media providing opportunities for students to practice their lessons outside the classroom. In addition, the management of a reading class usually encounters with a large size class and the limited teaching time. The use of e-learning system or Moodle was suggested at Burapha University. However, the university server may not be able to serve large amount of users. This study, therefore, evaluates the use of Edmodo whether it can be equivalent to the use of university Moodle. The subjects were 54 undergraduate students studying Reading in Business English in the academic year 2014. They were divided into 11 sub-groups for their group presentations and other online quizzes. Online observation was used to study the use of Edmodo during the semester whereas close-ended and open-ended questionnaires were distributed at the end of the class to find students' attitudes toward the use of Edmodo as the learning tool in reading class. The findings reveal that students report positive attitudes toward Edmodo in terms of users friendly function and interaction between students and teacher. Hence, the study suggests that teachers may consider the use of Edmodo in their reading class.
\end{abstract}

Index Terms-Business reading class, Edmodo, post-reading phase and, technology integration.

\section{INTRODUCTION}

Teaching English-language in Thailand where English is the foreign language for Thai students is relatively challenging as the students hardly find proper place to practice the use of English skills except in their classroom [1]. Also, an language teacher usually has limited teaching time in a classroom [2]. At Burapha University, Thailand, typically 50-55 English-major undergraduates attend a class of Reading in Business English for three 50-minute periods a week [3]. It is insufficient time to offer effective English language reading skills to the individual students. Consequently, this may lead to low proficiency on English reading competence [4].

It was suggested in many English teaching textbooks and research articles on reading skills [2], [5], [6] that English reading lessons should be divided into pre-reading, during-reading or while-reading and post-reading phases. In addition, teachers play the dominant role to promote reading both in-class reading and out-of-class reading. On the other hand, with the time limitation, pre-reading and while-reading phases can only be conducted in class and post-reading phase rarely occurs in English reading classes.

To encourage students to get engaged in practicing their

Manuscript received June 2, 2015; revised December 2, 2015.

Rinda Warawudhi is with the Department of Western Languages, Faculty of Humanities and Social Sciences, Burapha University, Chon Buri, Thailand (e-mail: rinda@buu.ac.th). reading skills outside the digital 21st-century classroom, the use of social media may be the effective learning tools. It was found that social media or information technology has become a growing phenomenon for public and academic purposes [7]. Since the beginning of this decade, the use of social media as the learning tool became popular among academics and researchers [2], [8]-[16].

Currently, the use of Moodle (Modular Object-Oriented Dynamic Leaning Environment) is supported and sponsored by Burapha University. Teachers can assign on-line post-reading exercises for students to practice during the semester [17]. However, the students usually reported that the university server could not support the large amount of students to visit university e-learning system at the same time. Edmodo, an another social media tool for education, is similar to Moodle. It is allowed any teachers to create online quizzes and another learning exercises. In addition, it has the function allowing students to upload files to their class. The researcher, then, is interested in investigating whether the use of Edmodo can be equivalent to the use of university Moodle. Also, the researcher would like to evaluate whether Edmodo can be used as the learning tool for English reading pedagogy or not.

\section{LITERATURE REVIEW}

As Edmodo is relatively new to teachers who may be digital immigrants. This section provides the definition and its functions as well as the research studies about this social media as a learning tool.

\section{A. What Is Edmodo?}

Edmodo - a microblogging platform- was used as an online learning platform. Edmodo (http://edmodo.com) is viewed as Facebook of schools by a number of teachers [18]. Using Edmodo, students and teachers can reach out to one another by sharing ideas, problems, and helpful tips. A teacher can assign and grade students' work on Edmodo; students can get help from the entire class on Edmodo. It is a safe environment. Also, parents can join the class to bring a level of transparency that is difficult to achieve without technology [19].

Scott [20] pointed out the capacities of Edmodo that attract many teachers and educators to apply this social media in their classes. The capacities of Edmodo are as the following:

1) Users friendly - It is easy to use and there are the accounts for teachers, students, parents and co-teachers.

2) Mobile Access - Students can use it anywhere by the use of computer or mobile devices.

3) Peer Connections - It encourages the interaction between teacher- student and student-student.

4) Classroom management - It is available to post homework and quizzes, and organize group and so on.

5) Cost Savings - It is a free service. 
In this study, the researcher set up eleven subgroups for students to do out-of-class reading activities as well as to prepare for the presentation outside classroom. Figure 1 is a screenshot of group space. Over 17 weeks (one semester), the researcher constantly used the class space to provide online quizzes and communicated with students outside the classroom.

\section{B. Edmodo in Education}

Edmodo has been promoted to be used as the learning tool by many researchers and educators [10]-[15], [19]-[22].

It can be summarized as follows:

TABLE I: RESEARCH ON USING EDMODO AS LEARNING TOOL

\begin{tabular}{|c|c|c|}
\hline Author(s) & Course & Results \\
\hline $\begin{array}{l}\text { A.B. Nordind\& N. } \\
\text { Alias (2013) [14] }\end{array}$ & History & $\begin{array}{l}\text { It was found that the students } \\
\text { found their class came alive } \\
\text { and more interesting when the } \\
\text { teachers implemented social } \\
\text { media in their class. Also, } \\
\text { these teaching tools can } \\
\text { promote student engagement. }\end{array}$ \\
\hline A. Lie (2014) [13] & Pedagogy & $\begin{array}{l}\text { The researcher found that she } \\
\text { can become life-long learner } \\
\text { in her profession. At the same } \\
\text { time, with the use of Edmodo } \\
\text { by students can promote the } \\
\text { real participation as some } \\
\text { students presents in class but } \\
\text { with absent-mind. The shy } \\
\text { students can discuss and } \\
\text { express their voice in this } \\
\text { social media learning tool. All } \\
\text { in all, the majority of the } \\
\text { students enjoyed studying } \\
\text { with Edmodo. }\end{array}$ \\
\hline $\begin{array}{l}\text { C. Kongchan } \\
\text { (2012) [12] }\end{array}$ & $\begin{array}{l}\text { English } \\
\text { Skills and } \\
\text { Strategies }\end{array}$ & $\begin{array}{l}\text { It can be seen that even the } \\
\text { teachers who were not } \\
\text { familiar with technology } \\
\text { could implement Edmodo in } \\
\text { their class and the teachers } \\
\text { agreed that Edmodo could } \\
\text { support teaching and learning. }\end{array}$ \\
\hline $\begin{array}{l}\text { J. Lu \& D. } \\
\text { Churchill (2013) } \\
\text { [18] }\end{array}$ & $\begin{array}{l}\text { Learning } \\
\text { Object }\end{array}$ & $\begin{array}{l}\text { The results showed that } \\
\text { students generally reported } \\
\text { that Elgg enhanced social } \\
\text { interaction within the class } \\
\text { and created a sense of } \\
\text { community. On the other } \\
\text { hand, the results from the } \\
\text { study on Edmodo showed that } \\
\text { it supported individual }\end{array}$ \\
\hline \multirow[t]{2}{*}{ Author(s) } & Course & Results \\
\hline & & $\begin{array}{l}\text { learning and group } \\
\text { collaboration. }\end{array}$ \\
\hline $\begin{array}{l}\text { P.Ractham\& C. } \\
\text { Chen (2013) [15] }\end{array}$ & $\begin{array}{l}\text { Management } \\
\text { Information } \\
\text { Systems }\end{array}$ & $\begin{array}{l}\text { The findings indicated that } \\
\text { students were enhanced to } \\
\text { learn more and understood } \\
\text { more with the use of Edmodo. } \\
\text { The researchers also } \\
\text { concluded that this only social } \\
\text { technology can be used as a } \\
\text { case-based learning tool. }\end{array}$ \\
\hline
\end{tabular}

It is obviously shown in the results of research articles above that Edmodo can be implemented in the classroom as a learning tool; nevertheless, there were few studies in English language classroom. Therefore, the researcher is interested in providing out-of-class activities via Edmodo in order to enhance students' comprehension and engagement in business reading class.

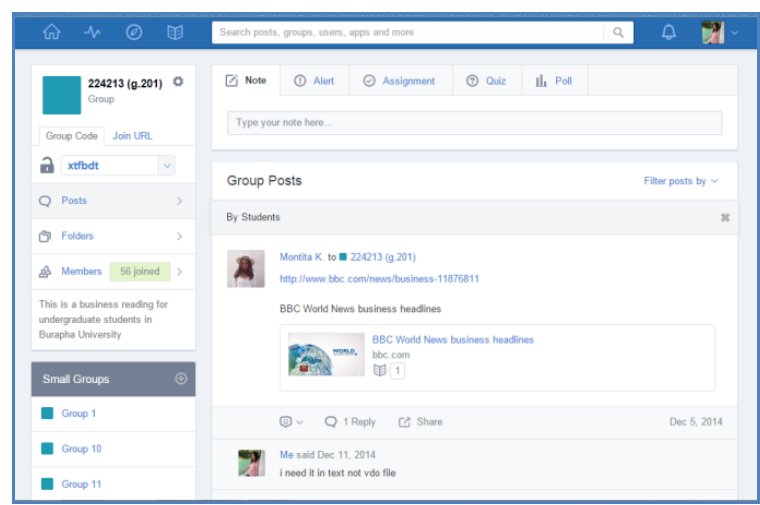

Fig. 1. The front page of Edmodo.

\section{RESEARCH QUESTIONS}

Three research questions in this action research were addressed in the following:

6) How well do the students use Edmodo as a learning tool outside business reading class?

7) What are the students' attitudes towards the use of Edmodo in business reading class?

8) What are students' problems and suggestions on the use of Edmodo in business reading class?

\section{Methodology}

The methodology of this action research can be divided into four parts:

\section{A. Subjects}

This study conducted in the first semester of the academic year 2014. It lasted approximately four months or the whole semester. The subjects were fifty-four undergraduate students studying Reading in Business English (subject code: 224213), which is a compulsory major course for undergraduate students majoring in English at Burapha University in Chon Buri, Thailand. They were all third year students and between 20-22 years old, which were considered as digital natives. As they were born around technology, they might get used to the use of social media in several purposes [13].

\section{B. Instruments}

Three instruments were utilized in this study as follows:

1) Questionnaire: Open-ended and close-ended questionnaires were distributed to the students to administer at the end of the course. The questionnaire is divided into two parts: Part One consists of the statements asking student's personal information and 17 five-point Likert scale statements attempting to evaluate students' attitude towards the use of Edmodo in each function as the learning tool for their reading class; and Part Two contains three open-ended questions asking students to identify problems and suggestions on the use of Edmodo in their reading class.

2) Edmodo: One of social media that can be used as a 
learning tool in and outside the classroom. In this study, 11 sub-groups had been set up to work together. All sub-groups of four to five students had to complete 10 online quizzes. Also, students were assigned to make group presentations on business reading. They can use Edmodo to consult with the teacher as well as to share the presentation files (PowerPoint) to their classmates. During the semester, students were urged to do polls and to share the useful files or websites for their peers.

3) Online Observation: The observation of the student's behaviors on the use of Edmodo out of their classroom. Students were persuaded to communicate outside the class using Edmodo in order to prepare their group presentations and to complete online quizzes. The frequency of posts and comments were calculated.

\section{Data Collection}

The orientation of the Edmodo program was conducted at the first week of the semester. Then students were divided into 11 sub-groups to do online activities and group presentations. First five online quizzes were uploaded in Week 3 and lasted five weeks for students to do before midterm examination as students were relatively new to the program and the other five online quizzes were uploaded after midterm examination and lasted four weeks. Group presentations started from Week 4 and lasted to Week 16 (2-week break for Midterm Examination). Each group was allocated one hour for a presentation. Students were urged to consult with the teacher via Edmodo. There were other online activities e.g. doing polls, sharing files, suggesting interesting online reading. At the end of the course (Week 16), questionnaires were distributed to the students to express their attitudes toward the use of Edmodo in their reading class.

\section{Data Analysis}

The students' interaction in Edmodo was observed in terms of posts and comments. Then, they were calculated by the frequency to examine how much the students got engaged to this out-of-class activities.

Also, 17 statements in closed-ended questionnaire (Part One) were evaluated by using SPSS software (frequency, percentage, mean and S.D.) The objectives of the items were to survey students' behavior to use Internet and Edmodo and to determine the students' attitudes towards this teaching method. These items can be interpreted according to the following levels:

- Strongly disagree (the lowest) $=1.00-1.80$

- Disagree $($ low $)=1.81-2.60$

- Moderate $($ medium $)=2.61-3.40$

- Agree $($ high $)=3.41-4.20$

- Strongly agree (the highest) $=4.21-5.00$

Moreover, three open-ended questions in Part Two will be categorized and analyzed to find opinions, problems and suggestions on the use of Edmodo in business reading class.

\section{RESUlts}

In this study, the results were presented according to three research questions as follows:

1) How well do the students use Edmodo as a learning tool outside business reading class?

The researcher had observed the use of Edmodo of the students to examine how frequently students interacted with teacher and their peers and it can be summarized in Table II as follows:

TABLE II: THE NUMBERS OF POSTS AND COMMENTS WRITTEN BY STUDENTS

\begin{tabular}{lllll}
\hline \hline & $\begin{array}{l}\text { No. of } \\
\text { students }\end{array}$ & Posts & Comments & Total \\
\hline Group 1 & 5 & 6 & 6 & $\mathbf{1 2}$ \\
Group 2 & 5 & 9 & 8 & $\mathbf{1 7}$ \\
Group 3 & 5 & 16 & 26 & $\mathbf{4 2}$ \\
Group 4 & 5 & 15 & 31 & $\mathbf{4 6}$ \\
Group 5 & 5 & 42 & 68 & $\mathbf{1 1 0}$ \\
Group 6 & 5 & 18 & 60 & $\mathbf{7 8}$ \\
Group 7 & 5 & 11 & 32 & $\mathbf{4 3}$ \\
Group 8 & 5 & 14 & 48 & $\mathbf{6 2}$ \\
Group 9 & 5 & 9 & 26 & $\mathbf{3 5}$ \\
Group 10 & 5 & 10 & 47 & $\mathbf{5 7}$ \\
Group 11 & 4 & 6 & 3 & $\mathbf{9}$ \\
Mean(s) & & $\mathbf{1 4}$ & $\mathbf{3 2}$ & $\mathbf{4 6}$ \\
\hline \hline Total & $\mathbf{5 4}$ & $\mathbf{1 5 6}$ & $\mathbf{3 5 5}$ & \\
\hline \hline
\end{tabular}

The data from online observation reveal the learning activities took place in group spaces where students prepared for the group presentations, did quizzes and shared resources. The average posts among 11 sub-groups were 14 as well as 32 comments. There were 5 groups that their comments reached the mean (Group 3, 4, 5, 6 and, 8) whilst there were 5 groups reaching the means in making comments (Group 5, 6, 7, 8 and, $10)$. Only three groups could make posts and comments with the frequency that reached the averages. They were Group 5, 6 and, 8. Below is the example of the posts made by a student from subgroup 5 (see Fig. 2).

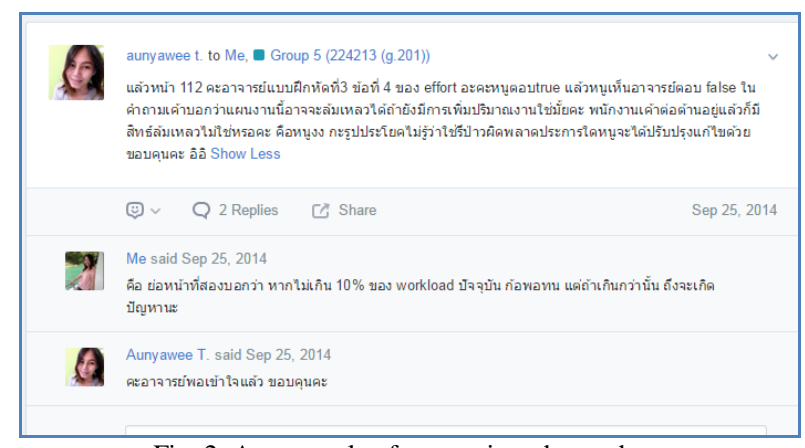

Fig. 2. An example of post written by student.

Questionnaires asking for student's personal data on their behaviors to use Edmodo have been distributed. It was found from 52 returned questionnaires $(96.29 \%)$ that almost every students (50 out of 52 students or $96.15 \%$ ) used their smart phones to connect to the Internet, 35 students or $67.30 \%$ used notebooks, 20 students or $38.46 \%$ used personal computers (PC) and 16 students or $30.77 \%$ used iPad or tablets to connect to the Internet.

In addition, students reported that the majority of them (32 
students or $61.54 \%$ ) used notebooks to do online exercises on Edmodo whereas 25 students of $48.07 \%$ did the online exercises via PC and smart phones. Only 6 students or $11.54 \%$ used iPad or tablets to finish their online exercises.

On the contrary, 39 students or $75 \%$ of them communicate with their peers and teacher in Edmodo through smart phones. 28 students or $53.85 \%$ used notebooks, 19 students or $36.85 \%$ used PC and 6 students or $11.54 \%$ used their iPad or tablets.

2) What are the students' attitudes towards the use of

Edmodo in business reading class?

To reach students' attitudes towards the use of Edmodo as out-of-class learning tool in business reading class, questionnaires were distributed to students at the end of the course consisting of 17 statements with 1-to-5 ratingscale was in Part One and three open-ended questions in Part Two. In Part One, the first nine statements were about the use of Edmodo functions and the last eight statements were to examine the students' attitudes toward the use of Edmodo in business reading class.

The first nine statements were

S1: This program is easy to $\log$ in and $\log$ out.

S2: Process to do the quizzes is easy and fast.

S3: Posting text or making comment is easy and fast.

S4: You have freedom to upload files and suggest websites.

S5: Uploading files is easy.

S6: Downloading files is easy.

S7: Voting is easy.

S8: Accessing exercises is possible at all time.

S9: Getting information or movements in the subject is convenient and fast.

Students reported on how much they could operate Edmodo as the learning tool outside the classroom as shown in Table III.

TABLE III: HOW STUDENTS USED EDMODO IN BUSINESS READING CLASS

\begin{tabular}{llll}
\hline \hline & n & M & SD \\
\hline S1 & 52 & 3.94 & 0.958 \\
S2 & 52 & 3.81 & 0.841 \\
S3 & 52 & 3.83 & 1.004 \\
S4 & 52 & 4.04 & 0.949 \\
S5 & 52 & 3.92 & 0.926 \\
S6 & 52 & 3.96 & 0.907 \\
S7 & 52 & 3.92 & 0.904 \\
S8 & 52 & 4.04 & 0.907 \\
S9 & 52 & 3.94 & 0.802 \\
\hline \hline
\end{tabular}

The results from the study indicate that the means of all nine statements are at the high level. S4 and S8 obtain the highest means $(=4.04)$ whereas the mean of S2 is at the lowest among nine statements $(=3.81)$. All in all, students enjoyed the process of downloading files and the possibility of doing exercises at all time. Students reported that they did not encounter the problems in using Edmodo but they might have slight problems in doing the quizzes (S2).

Another eight statements attempting to evaluate the students' attitudes toward the use of Edmodo in business reading class were:
S10: Doing exercises via Edmodo helps you understand your lessons.

S11: Doing exercises via Edmodo encourages you to study more.

S12: You gain more responsibility when doing exercises via Edmodo

S13: You have more class participation when doing exercises via Edmodo

S14: You have more learning motivation when doing exercises via Edmodo.

S15: You communicate with your classmates more when doing exercises via Edmodo.

S16: You communicate with your teacher more when doing exercises via Edmodo.

S17: You learn about application for education when doing exercises via Edmodo.

The results can be shown in Table IV.

TABLE IV: STUDENTS' ATTITUDES TOWARD THE USE OF EDMODO IN BUSINESS READING CLASS

\begin{tabular}{llll}
\hline \hline & $\mathbf{n}$ & $\mathbf{M}$ & SD \\
\hline S10 & 52 & 3.6 & 0.823 \\
$\mathbf{S 1 1}$ & 52 & 3.77 & 0.942 \\
$\mathbf{S 1 2}$ & 52 & 3.88 & 0.983 \\
$\mathbf{S 1 3}$ & 52 & 3.71 & 0.977 \\
$\mathbf{S 1 4}$ & 52 & 3.48 & 0.939 \\
$\mathbf{S 1 5}$ & 52 & 3.65 & 0.968 \\
$\mathbf{S 1 6}$ & 52 & 3.98 & 1.129 \\
$\mathbf{S 1 7}$ & 52 & 3.9 & 1.125 \\
\hline \hline
\end{tabular}

It can be seen that all eight items obtain the mean scores at the high level. In fact, the mean of S16 is the highest (=3.98) as well as the mean of S14 is the lowest $(=3.48)$. It can be assumed that the students can do out-of-class reading exercises on Edmodo. They reported that they could communicate with teachers more (S16); however, they might not have the motivation in study business reading through this program (S14).

In addition, the responses to the first open-ended question in Part Two were analyzed to answer 2nd research question. The question was:

Q1: What do you think of doing activities via Edmodo in Reading in Business English subject?

The results of Q1 showed 21 students mentioned that doing activities in Edmodo is convenient whilst five students (no.3, 36, 37, 42 and, 52) thought that the interaction between teacher and students outside the classroom was better. Moreover, five students (no. 22, 25, 34, 41 and, 49) perceived Edmodo as a new trendy teaching media. However, there were five students felt negatively with Edmodo. One student (no.5) preferred the university e-learning system (Moodle) and three students (no.7, 8 and 20) said that they had the problem doing online exercise via smart phone.

3) What are students' problems and suggestions on the use of Edmodo in business reading class?

To answer this question, two open-ended questions were asked. The questions were:

Q2: What are the advantages and disadvantages of doing 
activities via Edmodo in Reading in Business English subject?

Q3: What are your suggestions for doing activities via Edmodo in Reading in Business English subject?

The answers from Q2 can be summed up that nineteen students said that the advantage of Edmodo was its users friendly. They could post, make comments, share files and do online quizzes easily. Four of them said that they gained more responsibility (no.2, 6,29 and, 35) and learned more (no. 19, 29, 33 and, 52). Also, the interaction between students and teacher increased (no. 27,36,38 and, 50). However, twenty students reported that they had problems doing online quizzes via Edmodo. It was relatively difficult to do quizzes on smart phone, Ipad or tablet (no. 7, 18, 21, 26, 31 and 35). Six students mentioned that there were no notifications of new activities unless they accessed to the program (no. 13, 27, 30, 36 and, 52).

The results from the study on Q3 show that students would like to have notifications on new activities via Facebook or SMS (no. 27, 28, 29, 36, 39 and, 52). Student number 42 prefers the communication with another class as they can discuss about the group presentation and other school work (There is another class of the same subject using Edmodo). Some students suggest using Edmodo in another classes and suggest this program to other teachers.

\section{DISCUSSION}

This paper studies the evaluation of Edmodo in business reading class using three instruments: Questionnaire, Edmodo and Online observation. To examine whether Edmodo can be used as an out-of-class learning tool. The findings from online observation indicate that even Edmodo is new to the students and none of them had used this program before, students could participate in the program doing quizzes, polls, posts, making comments and sharing resources on the program with small problems on the use via smart phones. It was found from online observation that sub-group 1,2 and 11 participated less than their peers in other groups. For the first two sub-groups, the causes of less participation may be from the time to get used to the program - they presented their group presentations in Week 4 and 5. Actually, they did have the discussion with the teacher but in other means of social media, e.g. Facebook and Line. The students from sub-group 11 also chatted with the teacher but the numbers of comments were relatively low. This might due to the fact that they had to complete several assignments from other subjects at the end of the semester.

It can be noticed from the close-ended and open-ended questionnaire that Edmodo can be applicable as a learning tool outside reading classroom to provide out-of-class reading phase for the students. Students reported that they could use the functions of Edmodo (users friendly) and the program empowered students to upload files and suggest websites to their peers. Also, with this program, class engagement and interaction between students and teacher were created. Nevertheless, students also informed the problems when doing quizzes that they did not get the notifications and that they might have problem when doing quizzes on smart phones.

\section{CONCLUSION}

All in all, Edmodo can be used as a learning tool for out-of-class activities for business reading class. Students could use the program as well as they were encouraged to get engaged to the lessons outside classroom by doing quizzes and making discussion with teacher for their group presentations. It is suggested for further study in the digital 21 st-century classroom that there should be a study on other new technology to be used among English teachers and students.

\section{ACKNOWLEDGMENT}

I would like to acknowledge the Faculty of Humanities and Social Sciences, Burapha University for granting the fund to do this research. My thanks also go to the EFL students studying at Burapha University for participating in this study.

\section{REFERENCES}

[1] A. Wiriyachitra, "English language teaching and learning in Thailand in this decade," Thai TESOL Focus, vol. 15, no. 1, pp. 4-9. 2002.

[2] I. Homidon et al., "Potential of Twitter in post-reading activities among community college students in Malaysia," Social and Behavioral Sciences, vol. 103, pp. 725-734, 2013.

[3] Registration Office, "Class information" Burapha University.

[4] S. Chtchumlong, "EFL student perspectives on formative e-assessment: A case study of Burapha University," in Proc. ICER 2012: Challenging Education for Future Change, pp. 511-518.

[5] T. S. C. Farrel, Planning Lessons for a Reading Class, Singapore, SEAMEO Regional Language Centre, 2002, pp. 15-16.

[6] J. Harmer, The Practice of English Language Teaching, Essex, Pearson Education Limited, pp. 211-227, 2006.

[7] C. Davis III et al., Social Media in Higher Education: A Literature Review and Research Directions, 2012, pp. 1-6.

[8] H. Bicen and N. Cavus, "Twitter usage habits of undergraduate students," Procedia Social and Behavioral Sciences, no. 46, pp. 335-339, 2012.

[9] E. Danciu and G. Grosseck, "Social aspects of Web 2.0 technologies: Teaching or teachers' challenges?," Procedia Social and Behavioral Sciences, no. 15, pp. 3768-3773, 2011.

[10] T. Fernandez-Ulloa, "Teaching with social networks: Facebook, Twitter and Edmodo," presented at 16th Annual CSU Teaching Symposium, California, USA, February 22-23, 2013.

[11] C. Holotescu, G. Grosseck, and E. Danciu, "Educational digital stories in 140 characters: Towards a typology of micro-blog storytelling in academic courses," Procedia Social and Behavioral Sciences, 116, pp. 4301-4305, 2014

[12] C. Kongchan, "How a non-digital-native teacher makes use of Edmodo," presented in International Conference 'ICT for Language Learning', 2012.

[13] A. Lie, "Social media in a content course for the digital natives," TEFLIN Journal, vol. 24, no. 1, pp. 48-62, February, 2013.

[14] A. B. Nordin and N. Alias, "Learning outcomes and student perceptions in using of blended learning in history," Procedia Social and Behavioral Sciences, vol. 103, pp. 566-585, 2013.

[15] P. Ractham and C. Chen, "Promoting the use of online social technology as a case- based learning tool," Journal of Information Systems Education, vol. 24, no. 4, pp. 291-297, 2013.

[16] J. Banitt, S. Theis, and L. V. Leeuwe, "The effects of technology integration on student engagement," Thesis, St. Catherine University, St. Paul, Minnesota, USA, MAED, 2013.

[17] Teaching Learning and Innovation Division, Burapha University.

[18] J. Lu and D. Churchill, "Creating personal learning environments to enhance learning engagement," in Proc. 2013 IEEE 63rd Annual Conference International Council for Educational Media (ICEM), pp. 1-8, 2013.

[19] P. Cauley, "A guide to explain it all: Edmodo version 3.1.," 2012.

[20] S. M. Scott, "Go ahead... be social: Using social media to enhance the twenty-first century classroom," Distance Learning for Educators, Trainers, and Leaders, vol. 9, no. 2, pp. 54-59.

[21] E. Dobler, "Flattening classroom walls: Edmodos take teaching and learning across the globe," Reading Today, pp. 12-13. 
[22] J. Mao, "Social media for learning: A mixed methods study on high school students' technology affordances and perspectives," Computer in Human Behavior, vol. 33, pp. 213-223, 2014.

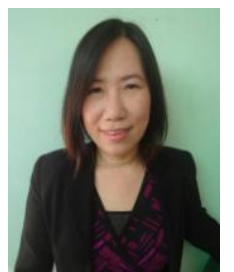

Rinda Warawudhi was born in Chon Buri, Thailand. She graduated her BA in English from Burapha University Thailand and her MA in applied linguistics from Kasetsart University, Bangkok, Thailand.

She started her career as an English lecturer at Rajabhat Rajanakarindra University in Chachoengsao,

Thailand in 1999. Since 2006 she has moved to work as an English lecturer for the Department of Western Languages, Burapha University in Chon Buri, Thailand. She has become a chair of BA (English) Program since 2011. As her department at the University organized ICLLCS2013and 2015 Conference, she was responsible for public relations work both domestically and internationally.
On the conference days, she played a role as a chair in TEFL section to introduce and present the certificate for presenters. She also organized the post-conference trip for all of the presenters.

Her first research article was 'A Comparison of the Achievement of First Year Students in English II (222102) Class via Student Teams-Achievement Division (STAD) Method and Lecture Method' which she had presented the first half of the research at the 9th AsiaTEFL, South Korea in 2011 and again the whole research paper at the 11th SEAAIR, Thailand in November 2011. She won Best Paper Award there and she had an opportunity to be a representative of SEAAIR to present her paper at AIR2012 in New Orleans, USA. Her paper was also published in JIRSEA, June 2012. Her second research article was presented at ACE2013, Osaka, Japan in 2013. The topic was 'Problem Analysis of English Major Undergraduate Students on Internship: A Case Study of Burapha University '. 